\title{
Association between socio-economic status and anxiety among women deserted by NRI husbands in Doaba region of Punjab
}

\author{
Shiksha Rani
}

Received: 28.03.2019; Revised: 10.05.2019; Accepted: 20.05.2019

Author for correspondence :

\section{Shiksha Rani}

Department of Human

Development and Family Studies, Punjab Agricultural University,

Ludhiana (Punjab) India

Email : sharmashiksha07@

gmail.com
ABSTRACT : Present study was an attempt to assess the association of socio - economic status with anxiety among the deserted wives by NRI husbands in Doaba region of Punjab. Four districts namely Hoshiarpur, Jalandhar, Nawansahar (Shaheed Bhagat Singh Nagar at present) and Kapurthala were purposively selected. A total sample consisted of 60 deserted women, asymmetrically distributed over the four districts because of the distinct feature of the study. From each district, respondents were selected by using PPS (Probability proportional to size) and snow ball sampling techniques. These results revealed that majority of deserted women were from upper-lower socio-economic class and faced high level of anxiety irrespective of socio-economic status. The results emphasize the need to start the psychological counseling and consultancy services for deserted women.

KEY WORDS: Deserted wives, NRI husbands, Socio - economic status, Anxiety

- HOW TO CITE THIS PAPER : Rani, Shiksha (2019). Association between socio-economic status and anxiety among women deserted by NRI husbands in Doaba region of Punjab. Asian J. Home Sci., 14 (1) : 190-193, DOI: 10.15740/HAS/AJHS/14.1/190-193. Copyright@ 2019: Hind Agri-Horticultural Society. 